\title{
Notes from a forum on the assessment of nitrogen requirements
}

\section{Strathspey Hotel, Aviemore (3 October 1979)}

The Chairman, Professor Greenhalgh, opened the meeting by pointing out that a forum in ancient Rome was a place for all to take part in open discussion, and could be contrasted with that other Roman institution, the circus, in which many spectators watched a small number of gladiators who were often foreigners. He compared circuses to modern international congresses which many of those in the current forum had recently attended. He mentioned that he had come prepared with names of people he would not hesitate to call upon should the discussion flag. In the event there was no necessity for such stimulation.

Dr. Braude opened the discussion, stating his view that the factorial method, although instructive, provided insufficient information for it to be relied upon in practice. He drew attention to individual pig differences in enzyme secretion. $\mathrm{Dr}$ $E$. $L$. Miller supported this view up to a point. He said that addition of factors in arriving at an estimate involved the addition of errors, though some may cancel out. For example, the nitrogen required by the ruminant for maintenance and also that provided in the form of microbial yield were both in his opinion underestimated and therefore the errors cancel. The factors recommended by the Agricultural Research Council will change with time, and the alteration of one will upset the balance. However, he agreed that some form of factorial approach was required initially to give a first estimate. The Chairman asked how one could take account of the inter-animal variations mentioned by $\mathrm{Dr}$ Braude who replied that he found the exercise of seeking protein requirements of "pigs" to be futile, and no longer bothered. Professor Fleck interposed that assessment was necessary in medicine. $\mathrm{Dr}$ Topps said that farmers must have a guide. $\mathrm{Dr}$ Corbett thought that for the ruminant, protein nutrition had been studied in more depth than had energy requirements and felt more effort was needed in respect of energy. $\mathrm{Dr}$ Ørskov approved of the principle of factorial estimates but maintained that these must never be rigidly adhered to; he cited his own observations of the interconversion of endogenous urinary- and metabolic faecal-N. Returning to requirements $\mathrm{Dr}$ Suttle warned against measuring amino acid requirements with techniques involving the use of $\mathrm{N}$-free diets. $\mathrm{Dr}$ Smith felt it was dangerous to lump together metabolic faecal- $\mathrm{N}$ and endogenous urinary- $\mathrm{N}$, because of losses due amongst other things to enzymes and Professor Lloyd-Davies suggested that endogenous losses per unit body-weight were affected by the fatness of the animal. Against the use of factors, Sir Kenneth Blaxter referred to the misplaced effort which had resulted from the Food and Agriculture Organization protein estimates for man. The FAO had claimed, on the basis of the calculated factors, that protein malnutrition had been eliminated. He felt that there was nothing wrong with calculating average requirements so long as the fact was understood. The $0029-665_{1} / 80 / 3913-3407$ 501.00 (C) 1980 The Nutrition Society 
Chairman asked if an imprecise estimate was worse than no estimate. $\mathrm{Dr}$ Braude considered that by using factors we gave the impression we knew more than we did, but $\mathrm{Dr}$ Buttery's request for an example of a wildly incorrect result obtained by using factors produced no reply.

The Chairman asked for a definition of maintenance in relation to amino acid turnover. $D r$ Millward stated that amino acids are reutilized efficiently and their turnover did not impose a large maintenance charge. Dr Reeds felt that 'allowance' and 'requirement' were frequently confused, and said that estimation of amino acid 'requirement' was possible but was expensive. He thought we could debate the physiological basis of maintenance requirement for ever, but pointed out that some similar concept had to be adopted in order to explain results. Sir Kenneth Blaxter agreed, and suggested that the greater the flux through the cell wall the greater was the oxidative loss of amino acids. Dr Millward disagreed, saying that branchedchain amino acids were oxidized in skeletal muscle where the flux is low, while other amino acids were oxidized in the liver where flux is high. Dr Mathers considered that there was a minimum rate of amino acid oxidation. Dr Reeds thought that protein intake and energy intake affected amino acid catabolism but in different ways. Dr Fuller stressed the importance of the loss of intact protein. He felt that there must be an element of empiricism in the factorial approach, and it is unlikely that we shall be able to quantify and obtain a figure for each amino acid. The amino acid requirement is meaningful only for a particular specified product, and there is a need to go back to the dose-response information. $\mathrm{Dr}$ Braude remarked upon the importance of the genetic background and referred to quoted figures of, say, $60 \mathrm{~g} \mathrm{~N} / \mathrm{d}$ absorption against $120 \mathrm{~g} \mathrm{~N} / \mathrm{d}$. Dr MacRae pointed out that many individual observations are combined to give a requirement value. He reiterated that the physiological state of the animal determines its own nutrient utilization. $\mathrm{Dr}$ Smith said that the figure for microbial-N yield in the ARC recommendations had been obtained by consideration of published values, but another speaker, Professor Taminga, thought the figure was too high.

Dr Thomas said that we must remember not to ignore the non-essential amino acids. They, too, must be synthesized in the rumen. Dr Ørskov felt we should not regard the ARC figures as final. The situation was dynamic and we must be prepared for changes. $\mathrm{Dr}$ MacRae questioned the ARC claim that degraded $\mathrm{N}$ is converted in the rumen into microbial-N with $100 \%$ efficiency. Dr E. L. Miller defended the statement but said the efficiency was only apparently $100 \% . \mathrm{Dr}$ MacRae said that calculations based on experiments using ${ }^{15} \mathrm{~N}$ indicated that the efficiency was probably only $60 \%$ if $\mathrm{N}$ all came from food protein. $\mathrm{Dr} \emptyset r s k o v$ said recycling had not been taken into account, and it was probable that insufficient information was available at the present time for a more accurate estimate. $\mathrm{Dr}$ Ulyatt castigated some participants for nit-picking. The ARC has provided a conceptual framework, he said, but does it provide a better basis for calculation? Dr MacRae advocated that with the limitation in finances, research must be based on 'experiments' and not description of static situations. Results are not yet available on the dynamic condition; should we continue to measure degradability 
etc. at, say, Rowett and NIRD? Or should we set up a new approach to this type of experiment? The Chairman pointed out the difficulty of testing the ARC on a small scale. Dr Suttle supported the idea of an ARC coordinated experiment, but Sir Kenneth Blaxter pointed out that in fact much validation had already been carried out with independent results from the literature, and the results incorporated in the ARC report. Dr Robinson introduced a breath of fresh Irish air by stating that if research should be cut on the grounds of insufficient funds, we should get down to basic principles. Let the farmers do the testing themselves, he said, using their own genotypes. He said that runners rather than commentators were needed.

Dr Fisher pointed out that factorial methods had been useful for the laying hen. If you have good empirical information only simple models are required. He admitted that this approach begs all the questions raised in the earlier part of the discussion. There were many outstanding questions remaining, but he thought that further work is unlikely to affect seriously the way we feed the hen. Dr Corbett introduced the question of environmental effects. In hot climates dietary amino acid concentration must be increased to maintain egg production. Sir Kenneth Blaxter pointed out that in man endogenous $\mathrm{N}$ excretion falls in hot climates. $\mathrm{Dr}$ Fuller agreed that climate is a factor which should be taken into account in a factorial system, and he felt that there was a case for accepting such a system to provide information for farmers (pace Dr Robinson!) Dr Braude returned to the pig and questioned whether it was rational to have a single requirement value for any particular class of pig. $\mathrm{Dr}$ Fisher again put his view that though requirements were irrational it was still rational to aim at a simple model. Dr Oldham compared requirement and response relationships, and asked what degree of tolerance was acceptable in practice? $\mathrm{Dr} \emptyset$ rskov referred to the importance of previous nutrition and genetic background. What is the requirement desired to achieve? In answer $\mathrm{Dr}$ Thomas said that the farmer must choose the best option.

In conclusion, $\mathrm{Mr}$ Palmer of ADAS put the farmer's point of view. He thought the research worker should choose an $80 \%$ precise model rather than attempting the impossible, but at the same time standards must not be reduced too far. Industry should be encouraged to aim higher and the research worker should not lower standards to meet the existing situation. He concluded that research work must aim high. 